\title{
Civilização de trabalho ou civilização do lazer?
}

\author{
ROBERT CHENAVIER
}

\author{
Atualidade do pensamento \\ de Simone Weil
}

$\mathrm{O}$

CONCEITO DE TRABALHO não-servil, em Simone Weil, apóia-se numa filosofia da liberdade resumida no seguinte trecho de Réflexions sur les causes de la liberté et de l'oppression: "a liberdade verdadeira não se define por uma relação entre desejo e satisfação, mas por uma relação entre pensamento e ação" (O.L., 115).

O livre cumprimento de qualquer obra, portanto, consistiria numa combinação de esforços "consciente e metódica, tanto quanto o pode ser a combinação de números pela qual se opera a solução de um problema quando procede de uma reflexão" (O.L., 116). É verdade que se trata de um ideal. No trabalho, porém, mais do que em qualquer outra atividade, é possível aproximar-se desse ideal, realizar uma adequação cada vez mais perfeita entre pensamento e ação.

Essa é a razão pela qual, nos escritos de Simone Weil, o trabalho ocupa - desde os primeiros até os últimos - um lugar central. Por outro lado, na perspectiva espiritualista de Simone Weil, é ponto essencial que o valor do trabalho está em permitir a libertação com relação à imaginação, às paixões, ao retraimento do eu, em exigir a suspensão de qualquer perspectiva individualista. Mas a possibilidade de uma espiritualidade do trabalho vem da capacidade de realizar nele a união perfeita entre a liberdade, identificada com a ação metódica, e a necessidade. Pois essa característica única, que pertence ao trabalho, impõe-se a toda forma de pensamento que procure acabar com a degradante divisão entre trabalho braçal e trabalho intelectual, o que, para Simone Weil, sempre constituirá um fim absoluto.

Marxismo e espiritualismo podem mergulhar a concepção do trabalho nãoservil em atmosfera diversa, elucidar diferentemente a relação entre liberdade e necessidade, interpretar de outro modo a necessidade, apresentar a liberdade como conhecimento da necessidade, conhecimento que permite dominá-la, como "sabor da verdadeira obediência" (E.L., 52), mas, de qualquer forma, o trabalho nãoservil nunca deixará de constituir o fundamento de uma "vida social bem ordenada" (E. col., Idées, 380). Seja ela chamada de socialismo ou de civilização fundada na espiritualidade do trabalho, uma vida social bem ordenada só pode assentar-se no trabalho enquanto ele é o único domínio no qual é possível ser realizada a adequação perfeita do pensamento e da ação. 
Ao desenvolver a espiritualidade do trabalho, Simone Weil salientou que o trabalhador é, por excelência, aquele que pode ter acesso ao sobrenatural e receber dele a luz (cf. C.O. col. Idées, 361). O que falta, são os "intermediários" (ib.) capazes de orientá-lo para o sobrenatural. Ora, o trabalho possui todas as características de um intermediário, daquilo que Simone Weil chama de metaxu, ou seja, uma realidade temporal e social que permite à alma abrir-se ao sobrenatural, ou a este nela enraizar-se (1). É, portanto, uma mesma pergunta que atravessa a obra toda: quais seriam as condições que tornariam possível uma organização social que tivesse como centro o trabalho não-servil?

Estamos chegando à principal dificuldade encontrada por Simone Weil (2): o surgimento de uma sociedade fundada sobre o trabalho não-servil é impossível sem a prévia dominação da classe operária na produção (uma vez que a constituição de uma classe dominante é sempre necessária antes dos abalos socio-políticos a que se dá o nome de revoluções), mas a grande indústria não comporta a possibilidade de tal dominação (por causa do aviltamento produzido pelo maquinismo e porque os trabalhadores, nessas condições, não passariam de simples peças de uma engrenagem).

Seria absolutamente necessário derrubar o taylorismo a fim de retornar, no trabalho, a uma relação verdadeira entre o pensamento e a ação, mas a grande indústria não encerra elementos próprios que assegurem essa reviravolta. Tem de existir uma correspondência entre a perfeição das formas da vida social e o estado da alma daqueles que participam dessas formas (assim como, inversamente, existe uma infeliz correlação entre as formas degradadas da vida social e o estado do pensamento dos homens). Como na obra de Platão, A república, o problema da comunidade em L'enracinement é o problema da alma, e as formas - perfeitas ou imperfeitas - das comunidades são avaliadas com relação à maneira pela qual possibilitam a satisfação das exigências da alma, daquela alma social que é o tema de L'enracinement, à medida em que a obra está destinada a fazer surgir uma espécie de milagre: "uma forma de vida social em que a coação 'não destruiria' a coisa delicada e frágil que não deixa de ser um ambiente favorável ao desenvolver da alma” (E.H.P., 110).

Em face da dificuldade - da impossibilidade - de encontrar na sociedade de seu tempo as condições necessárias para tornar real a possibilidade de um trabalho não-servil, parece mesmo que, por tipo de antecipação (a qual, no entanto, não é uma utopia), Simone Weil acentuava o estudo da vida social partindo das exigências da alma, deixando uma semente para o dia em que a realidade ofereceria as condições de satisfazer tais exigências. L'enracinement tenta definir o que seria uma civilização fundada na espiritualidade, mas, no momento em que Simone Weil escrevia sua obra, nunca havia sido tão larga a brecha, tão desesperadora também, entre as exigências por ela formuladas e a realidade.

Poderíamos dizer que Simone Weil não percebia, na realidade de seu tempo, meios de superar tanto o taylorismo quanto o maquinismo. Tal afirmação seria ao 
mesmo tempo verdadeira e falsa. De fato, se por um lado a racionalização tomava a forma do taylorismo, por outro, uma racionalização paralela contribuía para substituir o trabalho vivo pela automatização. Esse processo, já analisado por Marx, estava no centro das reflexões de alguns não-conformistas dos anos 30 (3), particularmente do grupo L'ordre nouvean, cujas teses foram formuladas por Robert Aron e Arnaud Dandieu em La révolution nécessaire (Grasset, 1933) - teses retomadas por Daniel Rops em longo artigo intitulado Por um futuro humano, publicado na coletânea L'avenir de la science (Plon, 1941). Constatando a tendência do processo de produção a eliminar o trabalho vivo, esse autores colocavam antecipadamente as bases, digamos para simplificar, de uma civilização do lazer, na qual o tempo disponível - e não o tempo de trabalho - seria a medida da verdadeira riqueza.

Simone Weil, que conhecia muito bem essas teorias, mostrou-se extremamente severa a respeito delas e criticou-lhes o conteúdo por duas vezes: em 1933 (ou 1934), em fragmento inédito (4) referente ao livro de Aron \& Dandieu e, em 1942, em artigo sobre L'avenir de la science, no qual atacava Daniel Rops (cf. S., 177 e ss.).

Precisamente porque por duas vezes, separadas por oito ou nove anos, ela formulou as mesmas críticas é que haveremos de nos perguntar qual constante de sua filosofia impediu Simone Weil de considerar a nova racionalização, ou seja, a automatização, uma eventual solução para os problemas que encontrava. Em outros termos, qual é o aspecto do seu pensamento que resiste à idéia de uma civilização não-fundada no trabalho?

É interessante notar que um texto de juventude - um ensaio escrito no decorrer do inverno de 1929-1930, e intitulado Fonctions morales de la profession (a ser publicado no tomo I de Oeuvres complètes) - já contém o princípio de todas as críticas ulteriores. Vamos partir do exame dessa longa dissertação.

\section{Conseqüências da separação do trabalho e da liberdade}

\section{O modelo grego \\ Separação da liberdade e da necessidade}

Pode-se ler no ensaio referido que a profissão constitui a solução do conflito entre o indivíduo (com seus direitos abstratos, sua liberdade abstrata) e a sociedade (puramente exterior e opressiva), conflito chamado por Simone Weil de "dialética da adolescência".

De fato, para o adolescente, a sociedade aparece "apenas como um regime egípcio, um sistema de castas, uma máquina na qual os homens nada representam além dos efeitos materiais por eles produzidos. A esse mecanismo o adolescente opõe seu mundo interior, sua vida de puro jogo, jogo dos músculos e jogo dos pensamentos" (Fonctions morales de la profession). 
Em suma, "a oposição entre o Egito e a Grécia se reproduz para cada adolescente" (ib.). O Egito é o sistema de castas representativo da sociedade; a Grécia, o momento de liberdade interior pura em que cada um é um fim para si mesmo e para os outros, em que se vivem a independência e o lazer. A Grécia, de fato considerava o trabalho algo servil. As ocupações dignas do homem eram a política, a eloqüência, os jogos, as artes, a geometria e a filosofia. O que Simone Weil censura nos gregos? O fato de terem conservado como imagem positiva do trabalho apenas a pura atividade; por exemplo, nesta definição do esporte: "O atletismo é a parte do trabalho que não é regulada por um objeto" (ib.).

Em outros termos, a parte do trabalho que os gregos valorizavam era a atividade, na medida em que ela não tinha relação alguma com a necessidade, finalmente, na medida em que ela não era um trabalho mas seu exato oposto, $\mathrm{o}$ lazer. A necessidade recaia inteiramente para o outro lado do trabalho, portanto, para o lado do escravo.

Por que tal cisão entre liberdade e trabalho no mundo grego? Exatamente porque desde que a atividade não é mais regulada por um objeto e se encontra isolada da necessidade, o trabalho, por seu lado, é apenas submissão à necessidade, em forma servil. Não sendo mais regulados por um objeto (particularmente o objeto da satisfação das exigências básicas) a atividade corporal e o espírito pensante (5) voltam-se exclusivamente para aquilo que tem seu fim em si mesmo - o que Aristóteles chamava de práxis (6) - e deixam a atividade laboriosa - a produção que tem seu fim fora da atividade em si mesma, ou seja, a poíesis (7) - para o escravo ou o artesão.

\section{Superação do modelo grego}

Poderíamos resumir o esforço constante de Simone Weil dizendo que ela quis, por sua filosofia do trabalho, superar a oposição entre práxis e poíesis. Por um lado, Simone Weil põe o agir (práxis) acima do produzir (poiesis). O que deve ser tomado por fim é a dignidade do trabalho (da atividade) e não o valor (da coisa produzida, como é o caso na fábrica, na qual o produto é mais valorizado do que a atividade, o que define propriamente a poíesis). É "por sua relação com o homem que o executa" que o trabalho manual deve se tornar o mais alto valor (O.L., 137). O fim da práxis é o aperfeiçoamento do agente.

Todavia, o valorizado é um agir que exige motivações que não sejam subjetivas, mas impessoais (8). Não é, portanto, o trabalho vivo enquanto atividade subjetiva que é valorizado; o consentimento à necessidade deve prevalecer sobre o projeto do indivíduo (9).

A necessidade, porém, não é exterior (como na poíesis) à atividade, pois a própria atividade, quando metódica, deixa-se reduzir a um jogo de necessidades. Dessa forma, supera-se a oposição entre práxis e poíesis. O indivíduo pode dedicarse a uma atividade cujo valor está no próprio agir (práxis) e não no produto, ao mesmo tempo que insere seu agir numa ordem exterior. Atividade e necessidade ficam de tal forma unidas que a necessidade deixa de ser servil e a atividade vazia; 
pois a atividade metódica do corpo e do pensamento, por um lado, e a ordem da necessidade sobre a qual opera essa atividade, por outro, estão em perfeito acordo. Uma vez que a necessidade deixa de ser exterior à atividade, desaparece o perigo de ela servilizar a atividade, a qual, por isso, já não tem motivo para fugir da necessidade como de outro alienante que a subjuga, abandonando-se assim a um funcionamento vazio, o da subjetividade entregue a si mesma. A atividade metódica penetra a necessidade, nela se inserindo e, com isso, de atividade vazia que era, passa a ser atividade livre. A necessidade penetrada de atividade metódica pensante e corporal exige então apenas o consentimento e não a submissão.

Uma atividade sem necessidade não é livre, mas vazia, uma necessidade não penetrada de atividade metódica serviliza. Por isso, quando trabalho e lazer opõemse, cindidos em dois domínios antagônicos, a liberdade é absurda e o trabalho servil. É esse, segundo Simone Weil, o modelo grego.

Como definir então o trabalhador livre? É "o corpo atleta e o espírito geometra tomando por objeto a satisfação das exigências básicas (Fonctions morales de la profession). Assim, o trabalho deixa de ser definido do único ponto de vista da heteronomia, como simples conseqüência das exigências básicas, simples dependência do homem; tampouco é definido apenas pela atividade: "O trabalho é uma relação entre a atividade e as exigências básicas" (ib.).

\section{O modelo grego invertido}

As perspectivas do modelo grego podem ser invertidas como, precisamente, Simone Weil o faz em Réflexions sur les causes de la liberte: "Mesmo as atividades aparentemente mais livres, como ciência, arte e esporte, só têm valor na medida em que imitam a exatidão, o rigor, o escrúpulo próprios dos trabalhos e até os exageram. Sem o modelo que thes fornecem (...) o lavrador, o ferreiro, o marinheiro, que trabalham com esmero, essas atividades se perderiam na pura arbitrariedade" (O.L., 114).

Por que essa inversão de perspectiva? Porque "são os obstáculos com os quais a pessoa se defronta e a necessidade de superá-los que lhe proporcionam a oportunidade de vencer a si mesma" (ib.). E só as coisas - a matéria - podem constituir um obstáculo. As atividades desinteressadas não poderiam, portanto, alcançar seu pleno valor, a não ser numa civilização do trabalho. Seria, por exemplo, o caso da arte: “... ela cristalizaria nas obras a expressão do feliz equilíbrio entre o espírito e o corpo, entre o homem e o universo, que só pode existir em ato nas formas mais nobres do trabalho físico; de resto, mesmo no passado, as obras de arte mais puras sempre expressaram o sentimento, ou, para falar de modo mais exato, o pressentimento de tal equilíbrio" (O.L., 139).

O pressentimento, uma expressão ainda inacabada, deverá ser levado à perfeição por uma civilização do trabalho, à qual cabe a tarefa de dar ao maior número possível a oportunidade real de expressar esse sentimento. 
Da mesma forma, o esporte, enquanto atividade desinteressada, seria, dentro de uma civilização do trabalho, uma atividade subordinada: "O esporte teria como fim essencial dar ao corpo humano a agilidade e (...) a fluidez, que o tornam permeável ao pensamento e possibilitam a este o contato direto com as coisas" (e, portanto, com os obstáculos, como acontece no trabalho) (ib.).

\section{Figuras geradas pela separação \\ do trabalho e da liberdade}

Fora desse confronto com as coisas, o qual define o trabalho não-servil (e permite traçar a figura do homem livre), apresentam-se várias situações negativas que podem ser caracterizadas por quatro figuras geradas pela separação do trabalho e da liberdade.

\section{O escravo}

Quando, no exercício do trabalho, o homem "fica submetido a outra coisa que não a própria que ele deve modificar, já não é um trabalhador, é um escravo" (Fonctions morales de la profession). Não é à matéria que o escravo se submete, mas à vontade de outro homem. Menos do que o homem de uma tarefa, o escravo é o homem de um homem (como Aristóteles o define): "Na medida em que a sorte de um homem depende de outros homens, sua própria vida não só lhe escapa às mãos, mas também à inteligência; ... em vez de ordenar e agir, é preciso que se abaixe, suplicando ou ameaçando; e a alma cai em abismos sem fundo de desejo e temor" (O.L., 127-128).

Não ser confrontado com o obstáculo da matéria é expor-se ao risco de ser submetido à vontade de outros homens. E como não se pode "nem penetrar nem manipular de fora o pensamento humano" (ib.) - enquanto isso é possível com a matéria -, assim como também é impossível, diante do pensamento do outro, ordenar, julgar e resolver - como se faz diante de necessidade material - fica-se entregue às paixões (temor, desejo) e ao comportamento mágico - abaixar-se, suplicar, ameaçar (10). Em contrapartida, é fornecendo à vontade obstáculos - e apenas obstáculos - que o trabalho liberta.

\section{O homem de lazer}

Existe, porém, outra situação, que consiste em estar desobrigado de qualquer confronto com as coisas e de qualquer submissão à vontade alheia. Nem acorrentado à vontade dos outros, nem libertado pelo confronto com as coisas, esse é o homem de lazer. É o homem grego, o homem livre. Como lembra Hannah Arendt (La condition de l'homme moderne), a liberdade significa, para o cidadão grego, estar liberto da esfera da penúria (não trabalhar), liberto das ordens alheias (não ser escravo), liberto enfim do comando. Ser livre é não ter obrigação de trabalhar nem de obedecer nem de comandar. 
A tal concepção, Simone Weil opõe: "Mesmo que o homem deixasse de estar submetido às coisas e aos outros homens, no que diz respeito a necessidades básicas e perigos, ele lhes ficaria ainda mais completamente entregue pelas emoções que dele iriam se apoderar visceralmente, sem trégua e das quais, de ora em diante, nenhuma atividade regular o protegeria" (O.L.,114-115).

O que permite adivinhar os espetáculos que uma civilização do lazer poderia oferecer: "Um povo de desocupados poderia se dar ao luxo de criar para si obstáculos, exercitar-se nas ciências, nas artes, nos jogos; mas os esforços decorrentes apenas da fantasia não constituem, para o homem, um meio de dominar as próprias fantasias" (ib., 114).

Desvinculadas do modelo do trabalho (11), as atividades "desinteressadas" (ou "livres"), no melhor dos casos, nos entregariam à "arbitrariedade", ao "capricho", no pior dos casos, à "loucura" (ib.).

\section{As sociedades primitivas}

Não há necessidade, aliás, de ir buscar em futuro utópico uma visão daquilo que seria uma sociedade de não-trabalho. As sociedades primitivas poderiam nos proporcionar o suficiente para representar a "única liberdade que se pode atribuir à idade de ouro” (O.L., 114): “...nos primitivos (...) se representa a relação entre o homem e o mundo sob um aspecto que não é o do trabalho mas o da magia. Entre eles e a rede de necessidades que (...) define as condições reais da existência interpõem-se, ao modo de uma cortina, todos os tipos de caprichos misteriosos aos quais se julgam entregues (O.L.,120-121) (12).

Convém examinar a fonte da mentalidade mágica, pela qual o homem se encontra submetido aos próprios caprichos. A fonte é a separação da atividade e do trabalho, ou melhor, é a dominação, na atividade, de uma habilidade que não é nem metódica nem laboriosa. Por quê? Porque "os movimentos do corpo vivo representam", nessas sociedades, "o papel principal na luta contra a natureza" ( $i b$., 120). Por isso, a idéia de necessidade dificilmente tem possibilidade de se formar. A natureza parece obedecer apenas aos desejos, ou repeli-los. Para que desapareça tal mentalidade mágica, é preciso que "o corpo vivo passe para o segundo plano e os instrumentos inertes para o primeiro" (ib., 121).

\section{O senhor}

Resta observar a última figura gerada pela separação da atividade e da necessidade.

Encontrar-se-ia na posição do senhor aquele que, liberto da penúria, não estaria obrigado a trabalhar e, liberto da obrigação de obedecer, não seria escravo; mas não estaria livre de comando. Senhor, mas nem por isso homem livre. É escravo dos próprios caprichos e déspota para com os outros, está entregue, ele também, ao mágico, porque, como o primitivo, “(ele) está às voltas com desejos aos 
quais nunca se contrapõe uma idéia clara de necessidade que lhe venha apontar um limite. Como não concebe outro método de ação a não ser comandar, quando lhe acontece $(. .$.$) comandar em vão, ele passa de repente do sentimento de um poder$ absoluto ao de uma impotência radical” (O.L., 128).

Incapaz e compreender os próprios sucessos, surpreso diante dos fracassos, o senhor vive na fantasia.

Recapitulando, a separação do trabalho e da liberdade ou da atividade e da necessidade leva a quatro figuras:

- a servidão - o escravo, que trabalha, mas não está apenas confrontado com a necessidade das coisas; está entregue, em primeiro lugar, à vontade dos outros;

- a da liberdade ilusória - o homem de lazer, que está liberto do trabalho e da autoridade do outro, mas escravizado a suas paixões, porque a liberdade separada da necessidade não é senão arbitrária;

- a da liberdade ilusória junto com despotismo exercido sobre os outros - $o$ senhor, é a figura mais negativa porque, ao despotismo que pratica contra os outros, está associada a escravização aos próprios caprichos.

- a da idade de ouro - os povos primitivos -, que precede o conhecimento da necessidade; nela, os homens estão entregues à mentalidade mágica.

Nem mesmo se pode dizer que, como em Hegel, a figura do escravo seja a mais positiva e o fator de desenvolvimento histórico capaz de conduzir à libertação, pois só o confronto com a necessidade, nas coisas, liberta. O fato de o escravo ser, antes de tudo, dependente da vontade dos outros impede que o trabalho servil seja formador e libertador. Tal fragilidade do escravo não poderia resultar em força ou liberdade. Não existe, portanto, em Simone Weil, uma dialética do senhor e do escravo. O confronto de uma fragilidade servilizada com uma ociosidade que transforma alguém em tirano de si mesmo não constitui um motor da História.

\section{A recusa de uma civilização do lazer}

\section{Crítica das formas contemporâneas do modelo grego}

\section{"L'ordre nouveau" e a sociedade dualista}

O espírito das críticas dirigidas contra o modelo grego formuladas desde 1929 é encontrado novamente no texto redigido contra o grupo L'ordre nouveau (13). 
O que dificulta a liberdade dos homens, segundo Aron \& Dandieu, não é senão o resíduo apagado das próprias criações. O verdadeiro problema de uma revolução seria conseguir que os homens deixassem de estar a serviço das coisas que eles mesmos inventaram. A solução preconizada por Aron \& Dandieu é assim resumida por Simone Weil: "Basta, para eles, separar completamente a esfera da atividade automática daquela da atividade criadora, o que é fácil, segundo dizem, já que a primeira pode, graças ao progresso tecnológico, ser reduzida a quase nada. O trabalho não-qualificado deixaria de ser executado por alguns desfavorecidos, durante a vida inteira; seria a tarefa de todos os jovens durante alguns anos de 'serviço civil'. O resto da existência seria consagrado ao trabalho qualificado e, principalmente, ao lazer (...). O trabalho industrial não-qualificado teria uma organização muito centralizada (...). Ao oposto, no que diz respeito à atividade criadora, tudo seria descentralizado ao extremo (14) (...)" (Fragment sur "L'ordre nouveau”).

Para além do espírito quimérico e perigoso (15) do projeto, o modelo grego é questionado: a separação da esfera do trabalho socialmente necessário, mas nãoqualificado, e da esfera da atividade criadora, consagrada parcialmente ao trabalho qualificado e sobretudo ao lazer.

Numa sociedade dualista como essa, as duas esferas seriam organizadas de forma completamente oposta. A esfera da necessidade seria, na realidade, a da servidão. A idéia de um serviço civil é, para Simone Weil, inaceitável. Ela escreve em 1942, a respeito do artigo de Daniel Rops: "Um povo submetido a curto período de trabalho obrigatório e não-remunerado só há de trabalhar de verdade sob a pressão de um poder central despótico e sob ameaça de castigos terríveis" (S., 179).

Quanto à esfera da liberdade criadora, essa seria na realidade a "ociosidade desmoralizante" que condenaria a grande massa a uma vida degradante, à de uma manada. Em sua crítica ao artigo de Daniel Rops, Simone Weil acrescenta: "Quanto aos longos anos de lazer, é preciso ser ingênuo (...) para não prever que alguns os dedicariam ao único jogo pelo qual os homens se apaixonam de verdade, o jogo cujo objeto é a dominação sobre os homens" (S., 179-180).

É interessante observar que, excepcionalmente, Simone Weil adota o ponto de vista freudiano, segundo o qual o trabalho absorveria um potencial considerável de energia, a qual, na falta de ser assim direcionada - para o trabalho - tomaria a forma de agressão do homem contra o homem.

\section{A redução da jornada de trabalho}

Restam as críticas dirigidas às propostas de redução do tempo de trabalho. A única passagem em que Simone Weil considera de maneira positiva tal redução se refere a um "plano de 'reenraizar' operário", no qual está previsto que "só haveria meia-jornada de trabalho, devendo o resto do tempo ser dedicado aos laços de companheirismo, ao aperfeiçoamento de um patriotismo de empresa, às palestras 
técnicas - destinadas a fazer com que cada operário entendesse a função exata das peças que ele produz e como as dificuldades são superadas pelo trabalho dos outros -, às palestras geográficas para ensinar a todos para onde vão os produtos que ajudam a fabricar (...). A esses elementos seriam acrescentados outros de cultura geral" (E., 98-99).

Em suma, liberar tempo para melhor trabalhar na empresa. Em outras palavras, eliminar a separação entre a esfera do trabalho e a do não-trabalho.

Ainda, por toda a parte de sua obra encontra-se em Simone Weil a denúncia do modelo grego. Pode-se ler, por exemplo, no artigo Experiência da vida de fábrica (1941): "Alguns anunciam uma diminuição, aliás muito exagerada, do tempo de trabalho; mas fazer do povo uma massa de desocupados que seria escrava duas horas por dia não é nem desejável, mesmo que fosse possível, nem moralmente possível, mesmo que materialmente o fosse. Pois ninguém aceitaria ser escravo por duas horas" (C.O., 344-345).

O significado da crítica está bem evidente. Já que na sociedade industrial é o mesmo homem que, considerado livre, está escravizado no trabalho, a solução, segundo alguns afirmam, consistiria em dividir o indivíduo, restituindo a necessidade ao trabalho e a liberdade ao trabalhador. Bastaria para tanto reduzir o tempo de trabalho. Ora, a divisão do trabalho já é uma divisão do indivíduo, uma vez que ela reparte entre indivíduos diferentes aquilo que pertence, de fato e de direito, a cada um: por exemplo, o pensamento e a atividade manual. Diminuir a jornada de trabalho servil para conceder mais tempo ao lazer resultaria então em agravamento da situação do indivíduo; à servidão no trabalho acrescentar-se-ia, no tempo de lazer, a ociosidade desmoralizadora.

Pela mesma razão, Simone Weil critica a tese da divisão do trabalho e a da redução da sua jornada - pelo menos enquanto concebida como solução para a alienação -, ou seja, a recusa da divisão do indivíduo. O mesmo indivíduo não pode ser "uma formiga durante as horas de trabalho" e "um homem durante as horas de lazer" (Fonctions morales de la profession). Não basta diminuir o tempo durante o qual um homem é escravo para fazer dele um homem livre. Pelo contrário, quanto mais curto for o tempo de servidão, mais insuportável ele há de se tornar: "Represente-se o negro do matadouro de Chicago, descrito por Dubreuil, cujo trabalho consiste em afundar, a cada minuto, uma faca na garganta de um porco; mesmo que esse negro disponha de muitas horas de lazer, sua vida não deixa de ser desumana" $(i b)$.

Daí a recusa do serviço civil - mesmo o de curta duração - tal como proposto por Aron \& Dandieu.

São, portanto, vários os níveis analisados na crítica da sociedade do lazer; em primeiro lugar, uma sociedade na qual se o homem não trabalhasse muito, seria entregue à ociosidade desmoralizadora, até mesmo às suas pulsões agressivas; depois, uma tal sociedade agravaria a divisão do indivíduo. Enfim, verifica-se, em 
Simone Weil, a recusa de considerar que progressos tecnológicos levarão por eles mesmos a uma sociedade de lazer.

No entanto, para além do maquinismo e da sociedade industrial, Simone Weil chega a examinar uma etapa correspondente à tecnologia automatizada. Como são vistos por ela os efeitos dessa tecnologia?

\section{A automatização: idéia quimérica da supressão do trabalho}

Entre os métodos que se oferecem ao homem para produzir mais e com menos esforço surge "a substituição do trabalho vivo pelo trabalho morto", a qual consiste em "entregar à matéria o que parecia ser o papel do esforço humano" (O.L., 73). O maquinismo foi uma das primeiras etapas dessa substituição. A última corresponde à tecnologia automatizada, cujo princípio "está na possibilidade de entregar à máquina não apenas uma atividade sempre idêntica, mas também um conjunto de operações diversas" (ib.).

O que se pode razoavelmente esperar do desenvolvimento da tecnologia automatizada? Obviamente, não pode ser a supressão completa do trabalho humano, embora essa técnica - admite Simone Weil - "possa se desenvolver indefinidamente" (ib., 75). A técnica não pode libertar o homem do trabalho, pois só o trabalho humano pode adaptar as propriedades da matéria inerte, as quais hão de continuar cegas e indiferentes, a determinados fins (cf. ib., 73).

Por outro lado, porém, a técnica pode libertar o indivíduo ao permitir a sua substituição pela máquina nas tarefas mais pesadas. Nesse ponto, Simone Weil é constante em suas afirmações (O.L., 159; C.O., 340; E., 79-80; C.I., 64-65).

Todavia, os germes de libertação presentes na tecnologia automatizada não deixam de ter inconvenientes. Os efeitos positivos da automatização transformamse em seu contrário. Tal processo é descrito por Simone Weil em Réflexions sur les causes de la liberté (O.L., 76 e 159):

- A diminuição do trabalho que se deve à automatização acarreta maior volume de trabalho, difícil e degradante nos ramos não-automatizados (por exemplo, nas minas das quais são extraídos os metais utilizados na fabricação das máquinas automatizadas). Encontramo-nos novamente diante do modelo grego: a libertação de alguns tem como condição o aumento da servidão de outros.

- A automatização leva também à necessidade de produzir sem limite (as máquinas automáticas só trazem vantagem se produzirem em quantidade maciça). Daí o surgimento de falsas exigências. Destinada a satisfazer as exigências essenciais do homem, a automatização suscita-lhe, ao infinito, desejos supérfluos. Liberta o trabalhador para sujeitá-lo ao consumismo e fazer do consumo a esfera dominante. Aí também transparece o modelo grego, no qual prevalece o usuário, enquanto o produtor fica subordinado. Ora, diz Simone Weil, uma sociedade ideal não pode ser aquela na 
qual predomina o interesse (material) do consumidor, mas, pelo contrário, aquela na qual predomina "a dignidade do homem no trabalho, o que representa um valor espiritual” (E., 103).

- Enfim, ao criar exigências artificiais, a sociedade automatizada cria, por isso mesmo, trabalho supérfluo. Como a produção do supérfluo é colocada no mesmo plano que a do necessário, ela se transforma, por sua vez, em acréscimo da quantidade de trabalho necessário. Destinada a libertar do trabalho necessário degradante, a automatização cria trabalho supérfluo (apresentando-o como necessário!).

Em tal sociedade, produção, consumo e trabalho humano são desviados de seu fim.

\section{Quadro teórico da sociedade menos livre}

Mas, sob os argumentos de ordem sócio-econômica, deve-se buscar uma razão mais profunda. A automatização faria com que a necessidade se deslocasse totalmente para o lado da matéria e ficasse totalmente ausente do espírito: "Poderíamos conceber, como limite abstrato, uma civilização em que qualquer atividade humana, tanto na área do trabalho quanto na da especulação teórica, estaria submetida, até nos mínimos detalhes, a um rigor inteiramente matemático, isso sem que ser humano algum compreendesse absolutamente nada daquilo que estaria fazendo; a noção de necessidade estaria então ausente de todos os espíritos de maneira muito mais radical do que entre os povos primitivos" (O.L., 126).

A comparação com os povos primitivos não é apenas uma imagem. Em alguns aspectos, Simone Weil vê na automatização algo semelhante ao retorno à dominação da natureza sobre o homem primitivo. Graças à tecnologia automatizada, o homem escaparia aos caprichos de uma natureza cega tão-somente para se entregar à necessidade, não menos cega, de uma segunda natureza. Pois a automatização realizaria o último estágio da sistematização da vida contemporânea descrita em Réflexions sur les causes de la liberté, sistematização pelo meio da qual o domínio do pensamento individual é substituído por regularidades estabelecidas nas coisas, "e que constituem o equivalente daquilo que seria o pensamento coletivo, caso a coletividade pensasse" (O.L., 145).

A coesão da ciência é assegurada por símbolos; a economia é regulada pela moeda; as funções de coordenação e direção são cumpridas pela organização burocrática. Só caberia ainda ao maquinismo transformar-se em sistema inteiramente automatizado, para que o pequeno volume de trabalho restante se deslocasse do universo da matéria para o universo dos símbolos (com a emergência da função de controle-vigilância). A perda de contato com a matéria no trabalho concluiria o processo de substituição do real por símbolos, substituição tão temida por Simone Weil (16). A sociedade automatizada seria assim uma sociedade sem possibilidade de metaxu (17), uma vez que a cisão entre atividade individual livre e necessidade material seria completa. 
Enfim, a sociedade automatizada é o simétrico da sociedade primitiva. Esta se situava aquém da necessidade e levava ao reino da magia. Aquela estaria além da necessidade e levaria ao reino do absurdo. É quando os instrumentos inertes passam para o primeiro plano da relação com a natureza que cessa o reino da magia. Mas quando os instrumentos inertes e sofisticados constituem uma segunda natureza (um verdadeiro reino técnico), retorna-se para a magia.

Enquanto a atividade corporal é a que prevalece na luta contra a natureza, a idéia da necessidade não consegue se formar. Quando atividade corporal e pensamento são totalmente excluídos da transformação da natureza, e a necessidade se cristaliza em processos puramente materiais e cegos, a atividade e o pensamento ficam entregues ao absurdo (cf. O.L., 145).

A automatização representaria, para Simone Weil, a última metamorfose - e a mais perfeita - de um pensamento separado do indivíduo, cristalizado num mecanismo inteiramente objetivo. Última e monstruosa cisão entre a necessidade material tornada autônoma, totalmente separada da atividade individual, e o pensamento livre de qualquer necessidade, ou seja, livre apenas para a fantasia, o absurdo, o vazio, a loucura. Não sendo a tecnologia automatizada propensa por natureza a se valer para sempre da reflexão metódica, mas, pelo contrário, a excluí-la para substituí-la por atividades condizentes com o método ou desvinculadas de qualquer necessidade (desinteressadas), pensamento e atividades ficariam entregues à extravagância.

Compreende-se melhor, nessa perspectiva, o interesse de Simone Weil por toda a reflexão que permitisse vislumbrar uma transformação técnica capaz, ao mesmo tempo, de nos livrar de um maquinismo alienante (o da grande indústria) e de nos preservar de uma automatização falsamente libertadora (18).

Recapitulando, encontramos as diversas possibilidades abertas pelo modelo grego de cisão dentro da atividade entre liberdade e necessidade:

- Uma repartição da liberdade e da necessidade entre individuos diferentes. Por exemplo, em Aron \& Dandieu, o serviço civil, que livra alguns da necessidade de trabalhar para condenar outros a um trabalho degradante. Aqueles que são livres reúnem aqui as figuras do senhor e do homem de lazer; é a tirania sobre o outro junto com a liberdade ilusória.

- Toda a liberdade está do lado dos homens e toda a necessidade nas coisas. Por exemplo, a automatização, que operaria a metamorfose da liberdade num resíduo irreconhecível e entregaria um povo todo a uma necessidade material opressora e misteriosa. O homem livre reúne aqui as figuras do homem de lazer e do primitivo; é a liberdade ilusória junto com a mentalidade mágica.

- Liberdade e necessidade distribuem-se dentro da existência do individuo. 
Por exemplo, a redução da jornada de trabalho. No mesmo indivíduo coexistem o escravo e o homem de lazer; é o trabalho escravizante junto com a ociosidade desmoralizante e a fantasia (19).

\section{Atualidade ou inatualidade de Simone Weil (20)}

$\mathrm{Na}$ terceira parte deste texto, um confronto entre as idéias de Simone Weil e as teses desenvolvidas por André Gorz (21) será estabelecido. Duas razões justificam tal confronto: em primeiro lugar, tanto para André Gorz quanto para Simone Weil, a crise do capitalismo não anuncia mundo novo algum, nem prepara de forma alguma os trabalhadores para se apropriar dos meios de produção, tais como existem, a fim de edificarem uma sociedade de liberdade; em segundo lugar, em certo sentido que haveremos de precisar, Simone Weil permanece guiada pela inspiração do movimento socialista tradicional. Ela acredita na possibilidade de realização de um trabalho social livre, com o qual o indivíduo poderia identificar-se. Pergunta-se quais as condições que tornariam possível, na esfera do trabalho necessário, a dominação do trabalhador sobre os meios e os fins de sua atividade.

André Gorz abandona tal crença e ignora a pergunta formulada por Simone Weil.

Atualidade

A abolição do trabalho em si mesma não seria libertadora

- A liberdade não pode ser o resultado de uma mutação tecnológica.

- A automatização corre o risco de transformar o lazer em consumo forçado - o qual se transforma então em ocupação assimilável a um trabalho merecedor de salário a fim de que se desenvolva o processo de produção (22) (Gorz, Les chemins du paradis, 83 e ss.).

- A redução da jornada de trabalho não é em si mesma emancipadora. Só contribuirá para a libertação dos indivíduos na medida em que o tempo liberado não constitua um tempo vazio, nem preenchido por uma organização alienante de lazeres.

Todavia, Simone Weil não percebe suficientemente que a redução do tempo de trabalho é um dos fatores de transformação das condições de trabalho. "Ninguém aceitaria ser escravo por duas horas", afirma Simone Weil. Mas poderíamos certamente responder que a redução da jornada de trabalho tornará inaceitável o trabalho degradante. A experiência da liberdade repercutirá necessariamente na esfera do trabalho (23).

\section{Recusa de uma sociedade dualista}

Uma sociedade dualista compõe-se, por um lado, de um núcleo de assalariados estáveis, qualificados, bem pagos e protegidos; por outro, de uma massa de 
subproletários, sem lugar definido na sociedade, semidesempregados, empregados em serviços temporários, ou pouco qualificados e mal pagos (pessoal de vigilância, limpeza, serviço doméstico, isto é, tipicamente o trabalho chamado de reprodução (24), que era o dos escravos na Antigüidade e o de numerosa domesticidade negra na África do Sul). Gorz, aliás, caracteriza a sociedade dualista, que constitui uma ameaça bem real, como "sul-africanização". Nesse tipo de sociedade, é como se os expulsos da produção "se disputassem o privilégio de vender seus serviços pessoais àqueles que conservam uma profissão, uma renda, um salário estável e confortável" (25). Simone Weil teria visto em tal sociedade uma nova versão do modelo grego, da sociedade escravocrata, na qual a libertação de uns funda-se na servidão dos outros.

\section{Duração do trabalho mantida em nivel artificialmente elevado para a produção do supérfluo}

A utilização de tecnologia para produzir mais faz com que todas as atividades sejam colocadas no mesmo plano: produção do útil e do inútil, do necessário e do nocivo. O sistema econômico tende então a funcionar de tal forma que sua única finalidade parece ser a de oferecer trabalho, produzir para as pessoas trabalharem, independentemente da utilidade do trabalho fornecido, sem se preocupar com a utilidade, o valor, o significado daquilo que é produzido. Como escreve André Gorz, uma fórmula que Simone Weil provavelmente não teria: "Quando uma sociedade produz para trabalhar, em vez de trabalhar para produzir, é o trabalho de modo geral que se encontra marcado pela perda do sentido" (Adieux au prolétariat, 100).

\section{Inatualidade}

\section{A automatização acaba com todo tipo de trabalbo}

Segundo Simone Weil, a automatização pode e deve suprimir todos os trabalhos degradantes. Ora, em sua forma atual, a automatização não se limita a suprimir os trabalhos menos qualificados, mas tende a acabar com qualquer tipo de trabalho, o que deve ser entendido em duplo sentido (Les chemins du paradis, 73).

- A informatização e a microeletrônica economizam tempo de trabalho; todas as pesquisas concernentes aos efeitos da automatização sobre o emprego levam a prever, no decorrer dos próximos 15 ou 20 anos, uma diminuição de mais da metade do trabalho assalariado, manual ou não-manual, tanto no setor industrial quanto no administrativo.

- O trabalho, onde subsiste, "já não implica em confronto direto do trabalhador com a matéria, cuja transformação já não resulta de uma atividade imediata, completa e soberana" (ib.). É dizer que a automatização suprime os ofícios, a confrontação do homem com a necessidade nas coisas, para substituí-los por uma simples relação com símbolos.

É verdade que Simone Weil havia considerado essa situação, a qual, porém, 
representava para ela uma via errada que deveria ser descartada; acreditava que nem o taylorismo nem o fordismo eram irreversíveis. Achava, da mesma forma, que a automatização não era inevitável $\mathrm{A}$ experiência mostrou que taylorismo $\mathrm{e}$ fordismo não eram reversíveis e o retorno a um modo de produção no qual seriam reconstituídos os ofícios, em pequenas unidades de produção, pertencia à utopia. Em todo caso, a esfera do trabalho socialmente necessário não poderia ser organizada assim (26) (ib., 137 e ss.). Muito menos, portanto, poder-se-ia esperar da automatização que reconstituísse o profissionalismo dos ofícios, já eliminados pela fase anterior.

A automatização tem como principal efeito a banalização das tarefas. Para ser exato, seria preciso observar que é justamente por os ofícios já terem sido parcialmente extintos na grande produção socializada que a automatização dos postos de trabalho se tornou possível. Na esfera do trabalho necessário, a banalização das tarefas é, portanto, duplamente inevitável. Tarefas banalizadas têm sido automatizadas e a automatização reforça a banalização.

Tal evolução tecnológica se choca com uma possível apropriação da produção social pelos trabalhadores, tal como Simone Weil a desejava. A marginalização do trabalho necessário, que se deve tanto à diminuição da quantidade de trabalho quanto à banalização das tarefas, tornam totalmente utópicas a idéia de poder operário e de gerenciamento da produção pelos produtores associa- dos, qualquer idéia de autogestão, pelo menos no que diz respeito à esfera de trabalho socialmente necessário.

Tal fato permite concluir que, nesse ponto, Simone Weil se mostrou dependente das idéias do movimento anarco-sindicalista (27). Poderíamos também dizer, da mesma forma, que herdou certas concepções (28) de Marx, segundo as quais o proletariado (29) deve conseguir assenhorear-se da totalidade das forças produtivas para desenvolver a totalidade de suas capacidades. Marx acreditava na possibilidade de serem realizados coincidentemente o desenvolvimento das capacidades individuais no trabalho e o das forças produtivas, quando viu nascer a classe dos operários de ofício, que se tornariam os protagonistas do anarco-sindicalismo. Citando André Gorz: "Ora, Marx se enganou (...) Sabemos que foi exatamente o contrário que aconteceu... A ascensão dos operários profissionais, seu poder na fábrica, seu projeto anarco-sindicalista representaram apenas um parêntese que o taylorismo e, sucessivamente, a organização científica do trabalho, a informatização e a robótica se encarregaram de fechar (Adieux au prolétariat, 34-35) (30).

Foi por as idéias desenvolvidas pelo anarco-sindicalismo aliarem-se ao elitismo profissional que os ideólogos do movimento puderam idealizar a supressão da divisão da atividade em trabalho manual e trabalho intelectual. Depois de taylorismo e fordismo terem dado forma a tal esperança, é forçoso constatar hoje que a diminuição da quantidade de trabalho necessário, a destruição dos ofícios e a banalização das tarefas são irreversíveis 
Querer ligar necessidade e liberdade na esfera do trabalho socialmente necessário tornou-se impossível, pois nela o trabalho vivo há de ficar cada vez mais marginalizado, desqualificado, banal e precário.

\section{Nosso dilema}

A questão de uma civilização do trabalho parece hoje anacrônica, se representar a reconciliação do homem com a produção do necessário. Não se trata então de escolher entre sociedade de trabalho e sociedade de lazer, mas entre uma sociedade de desemprego e uma sociedade de lazer (Ib., 195).

Uma sociedade de desemprego ou dualista é a que Simone Weil teria descartado por se tratar de uma sociedade fundada no emprego em tempo integral e vitalício de uma minoria, e na inatividade (ou no trabalho precário) da grande maioria. Mas como não é possível pensar uma sociedade que, fundada no desenvolvimento tecnológico conhecido atualmente, poderia garantir emprego em tempo integral para todos os indivíduos e por toda a vida, é necessário, com base na situação atual, definir o que seria uma sociedade não-servil.

Liberdade e necessidade não podem ser totalmente separadas sem que se esvazie a liberdade e se afunilem as capacidades que poderiam ser desenvolvidas. Nesse ponto, Simone Weil está com a razão. Sem se levar em conta que o próprio trabalho pode ser uma exigência da própria natureza e (por que não?) a prioritária.

Em se tratando porém da esfera da produção do necessário, o trabalho não pode ser, senão excepcionalmente, a primeira exigência a ser considerada. Querer integrar a liberdade à esfera do trabalho necessário, como o preconizava Simone Weil, não é nem possível nem desejável, pois a esfera do trabalho necessário não tem condição de se tornar o campo de realização da autonomia para todos. É verdade que aspectos penosos, como monotonia e opressão, devem ser eliminados do trabalho heterônomo (31), mas não se pode confundir uma libertação desse tipo nas relações de trabalho com autonomia (32), a qual implica que o trabalho efetuado possa ser assumido por livre vontade, e seu conteúdo e finalidade determinados por aqueles que trabalham, o que só pode ser excepcional na esfera do trabalho necessário. Ali a liberdade pode consistir apenas em trabalhar ao mesmo tempo com a maior dignidade e eficiência possíveis. A autogestão, pelos produtores associados - supondo-se que isso fosse possível - da produção do necessário nunca realizará o reino da liberdade (33).

A discussão e a crítica das teses de Simone Weil deveriam concentrar-se, a nosso ver, neste exato ponto: ao contrário do que pensava a autora de La condition ouvrière, a esfera do trabalho socialmente necessário não é, ou em todo caso deixou de ser, a mais apta ao confronto do indivíduo com a necessidade nas coisas, pelo menos numa sociedade industrial. Não se deve confundir, como o faz Simone Weil, necessidade de trabalho e confronto, no trabalho, com a necessidade nas coisas. Essas duas formas de necessidade estão tão longe de ser idênticas que a organização industrial do trabalho necessário nunca cessou (e é irreversível) de 
desqualificar e suprimir aos poucos os ofícios operários nos quais liberdade e necessidade encontravam seu mais feliz confronto.

A esfera do trabalho necessário tornou-se então inapta à reconciliação da liberdade e da necessidade. Em outras palavras, no quadro teórico de uma sociedade que seja a mais livre possível, cabe prever, entre a produção do necessário, organizada na escala de toda a sociedade (34), e a pura atividade individual (escrever ou pintar), uma esfera intermediária na qual os indivíduos poderiam trabalhar, inclusive produzindo algo necessário se assim o desejassem, ou seja, confrontar-se com a necessidade nas coisas, mas escolhendo os fins e os meios de seu trabalho, pois esta é a autonomia: alguém poder querer aquilo que faz.

Não há, forçosamente, contradição entre trabalho e autonomia, contanto que não se confunda o trabalho socialmente necessário, sempre heterônomo, com o trabalho enquanto atividade autônoma, a qual supõe que alguém escolha os fins e os meios daquilo que faz. Assim, seria possível escapar a um só tempo ao modelo grego e às contradições encontradas por Simone Weil (35).

Recapitulando, uma sociedade assim concebida, que evitasse os riscos referentes às sociedade dualistas, acertadamente denunciados por Simone Weil, poderia ser sumariamente descrita da seguinte forma:

- Não haveria repartição da liberdade e da necessidade entre indivíduos diferentes: o trabalho socialmente necessário seria um direito - e um dever para todos (esfera heterônoma) (36).

- Não seria concentrada toda a necessidade para o lado das coisas, enquanto a liberdade ficaria do lado dos indivíduos: a automatização da produção do necessário não transformaria a liberdade num resíduo irreconhecível, uma vez que a liberdade continuaria confrontada com a necessidade nas coisas, dentro da esfera intermediária do trabalho autônomo.

- Liberdade e necessidade, embora distribuídas dentro da própria existência individual, não o seriam na forma do trabalho servilizante e da ociosidade desmoralizante. O trabalho necessário (heterônomo) deveria ser o menos alienante possível; o tempo de lazer não seria compensação de um trabalho servil, mas tempo de ação laboriosa autônoma (e não tempo de lazer desmoralizante).

Ao renunciar-se a uma civilização do trabalho, nem por isso retorna-se ao modelo grego: o lazer não é o lazer nocivo, compensador do trabalho; tampouco aquele que se opõe ao trabalho. A heterogeneidade do trabalho e do lazer não se supera fazendo da esfera do trabalho necessário uma esfera de trabalho livre (é impossível), ou transformando todo tipo de trabalho em jogo (é utópico). A solução deve ser buscada numa sociedade cujo espaço seja descontínuo e comporte níveis diferentes de liberdade (37). 


\section{Forma filosófica da crítica (38)}

\section{O trabalho: um valor?}

A razão essencial da recusa, por Simone Weil, da civilização do lazer é que $o$ tempo de lazer significa para ela a emergência da subjetividade individual. O trabalho é um processo necessário, tanto quanto o raciocínio. A situação do homem que trabalha corretamente é semelhante à daquele que raciocina com rigor (39). É verdade que, no trabalho não-servil, o indivíduo não se acha privado de iniciativa, até pelo contrário. Mas, no caso, a iniciativa reduz-se apenas a integrar-se numa corrente de necessidade sem falha. A iniciativa do homem que trabalha é a possibilidade que ele tem - e lhe deve ser dada - de descobrir a necessidade e nela consentir. Enquanto atividade individual, o trabalho recebe seu significado de sua integração à necessidade.

Fora dessa inserção, a atividade subjetiva, segundo Simone Weil, é feita de arbitrariedade, imprevisibilidade, contingência. Não é produtora de sentido, mas de absurdo, fantasia, loucura. Daí a recusa da atividade livre como criação de si por si mesmo, desenvolvimento das capacidades subjetivas, realização de si mesmo. Até a idéia de busca da perfeição pessoal na arte é refutada (40). A única atividade livre é a des-criação (41), a qual funciona em sentido oposto ao desenvolvimento do eu. A atividade livre deve, segundo Simone Weil, estar isenta de motivo e objetivo ligados com a existência pessoal. Se ela pensa que o trabalho deve estar desvinculado de qualquer objetivo referente à existência, não é apenas por serem exigências básicas - o dinheiro, a existência nua, objetivos demasiadamente vis ou desesperadores -, mas porque o apego aos objetivos da existência pessoal impede que o trabalho seja processo de des-criação.

Em todos pontos analisados o pensamento de Simone Weil levanta problemas filosóficos temíveis. Em primeiro lugar, porque nada há de impedir que o trabalho seja antes de tudo uma atividade submetida às necessidades vitais e à preocupação da sobrevivência individual e específica. A finalidade do trabalho é a reprodução da vida e é isso que associa para sempre o trabalho a uma atividade que gira no círculo dos processos naturais, como bem o mostra Hannah Arendt em La condition de l'homme moderne.

Querer desvencilhar o trabalho da existência e da satisfação das exigências básicas é a mesma coisa que fazer dele uma atividade desligada da própria necessidade que o fez surgir, da necessidade vital de satisfazer exigências básicas (42).

Tal necessidade haveria de conferir algum valor ao trabalho? Simone Weil deprecia as atividades autônomas em nome do seguinte princípio: o obstáculo (a resistência da matéria, a necessidade) é a oportunidade de vencer a si mesmo. Alguém, todavia, poderia argumentar que, se é verdade que houve vitória sobre si mesmo graças ao trabalho, tal vitória não foi resultado de uma escolha. A liberdade que dela resulta não foi o fim diretamente procurado. Vencer a si mesmo no trabalho é uma necessidade vital, não um valor. 
O fato de o trabalho me impelir a me libertar (da imaginação, das paixões) não implica, de forma alguma, que a liberdade seja um valor digno de ser procurado, escolhido e assumido por si mesmo. Particularmente, não implica que essa vitória sobre si mesmo e essa liberdade sejam valores a promover para além da esfera do trabalho (pelo bem, pelo belo ou pela liberdade) e em campos diferentes (relações com o outro, ação política...).

Mesmo admitindo que a relação com a necessidade - a resistência da matéria no trabalho seja uma condição de aparecimento da liberdade, não resulta daí que a liberdade de fato surgida da relação de transformação da natureza seja um valor. Tal liberdade conquistada de fato precisa ser valorizada, transformada em projeto a ser desenvolvido por aquilo que é em si mesmo. É verdade, enfim, que o trabalho (como qualquer conduta vital resultante de uma necessidade) envolve condutas que pertencem a um plano superior (o da liberdade, da superação de si mesmo...). Mas a mobilização de tais valores no âmbito da necessidade não poderia determinar por si só a passagem para o plano superior (moral, estético ou espiritual), nem constituir o bastante para essa passagem.

Por que razão são considerados superiores os valores morais e estéticos? Porque o trabalho, em última instância, permanece um valor vital relativo e o suplemento de valor (absoluto) que se lhe pode conceder prende-se ao coeficiente de liberdade, beleza e desprendimento que ele tem a capacidade de integrar. A liberdade, como valor desejado por si mesmo, e a beleza, também como valor procurado por si mesmo, é que conferem ao trabalho não-servil um valor superior a seu valor relativo.

Será possível, nessas condições, considerar o trabalho o modelo de qualquer tipo de atividade livre, até mesmo de qualquer tipo de vida livre? Não estaria aqui em jogo a própria possibilidade de uma civilização fundada sobre o trabalho?

\section{O trabalho, modelo de todo tipo}

de atividade livre e vida livre

Simone Weil desejaria que o trabalho se tornasse pura atividade técnica, ou seja, uma atividade fundada sobre o saber daquilo que se faz, ou ainda, que a atividade do trabalhador prolongasse a atividade de invenção; que o funcionamento da máquina, a significação daquilo que ela faz, o modo como foi construída deixassem de ser um mistério. Havendo ruptura entre o saber técnico e a execução de uma tarefa, desenvolver-se-iam operações nas quais o trabalhador não entenderia nada, das quais ele não participaria. $\mathrm{O}$ fato de o trabalho passar a ser uma atividade técnica, significa, em outros termos, que constituiria “(uma) combinação de esforços tão consciente e metódica quanto pode ser a combinação de números pela qual se opera a solução de um problema quando procede da reflexão" (O.L., 116).

Essa combinação de esforços representaria o modelo de todo tipo de atividade livre e até de vida livre na qual "o homem teria constantemente em mãos a própria 
sorte; haveria ele de criar a cada instante as condições da própria existência por um ato do pensamento" ( $i b$. $)$.

Mas poder-se-ia afirmar da mesma forma - e seria igualmente verdadeiro que, longe de ser o indivíduo quem dobrou a necessidade aos próprios fins, foi o determinismo quem anulou o indivíduo, dobrando-o às suas leis. Pois pode-se dizer que "uma vida em que todas as dificuldades reais se apresentariam de certo modo como problemas e todas as vitórias como soluções postas em ação seria totalmente livre" (ib.). Entretanto, pode-se dizer também que seria uma vida da qual teria desaparecido qualquer parcela de liberdade, uma vida na qual o determinismo anularia o indivíduo dobrando-o às suas leis. Tal fato significaria um mundo "no qual todos os elementos de sucesso seriam dados", isto é, conhecidos e manejáveis como o são os símbolos da matemática?

Se um ideal desse tipo pudesse ser alcançado, a realidade desse mundo se esvaneceria em idéia. Seria um mundo sem resistência, a não ser aquela que opõe o pensamento ao pensamento (como na matemática). A liberdade reduzir-se-ia a decifrar o dado, a previsão verificar-se-ia infalivelmente. Ora o mundo real, a história, a política ou as relações com o outro constituem um entrelaçamento feito de contingência, acidental, fortuita, em suma, de imprevisível. É neste mundo que agimos, neste mundo que se exerce nossa liberdade pessoal e não num mundo ideal no qual todas as vitórias seriam soluções matemáticas postas em ação.

Se a liberdade é algo impessoal, então o mundo ideal concebido por Simone Weil é o da liberdade perfeita. Mas se a liberdade é mesmo algo pessoal, nesse mundo restaria à liberdade apenas a possibilidade de produzir o erro. Esse mundo seria a imagem daquele da matemática, no qual, se uma criança erra uma conta de somar "o erro leva a marca pessoal da criança"; mas caso ela proceda de forma totalmente correta, a pessoa dela está ausente de toda operação (E.L., 17). Simone Weil toma o modelo de todo tipo de atividade e vida livre ao trabalho, no qual a atividade fundada no saber daquilo que se faz é liberdade. Trata-se, no entanto, de uma liberdade impessoal que, ao se inserir num universo impessoal, cria com o mundo uma relação que não pode ser vivida como minha maneira de ser - no mundo.

Que nenhuma forma superior de liberdade possa ser alcançada na esfera do trabalho necessário, é uma afirmação com a qual podemos concordar. Mas não será exatamente ela que condena a idéia de uma sociedade fundada sobre a primazia do trabalho?

Que o trabalho domine a vida individual até constituir não apenas a ocupação principal mas também um modelo de atividade; que a esfera do trabalho e, mais ainda, a do trabalho socialmente necessário sirva de base para uma civilização, é a mesma coisa que operar uma aniquilação da liberdade pessoal de meus fins subjetivos. Numa sociedade como essa, eu realizaria fins que não seriam os meus, que não poderiam ser os meus. Seria convidado - essa seria a minha única liberdade pessoal - para consentir na necessidade; mas, na falta de uma relação subjetiva 
com esse mundo, na falta de tempo para exprimir a minha maneira de ser - no mundo (a não ser pelo trabalho e nas atividades subordinadas ao trabalho), minha vida seria um fracasso.

Ao fazer do trabalho o modelo de tal atividade impessoal que, se dominar a vida de cada um, permitirá que ele anule esse eu não-essencial, será que Simone Weil não nos pede que saltemos para fora da condição humana?

Notas

1 Os metaxu possibilitam, ao mesmo tempo, à alma a via ascendente e ao sobrenatural a via descendente. Os metaxu transbordam os limites da vida social, mas as formas da vida social - e particularmente o trabalho - têm um papel fundamental. Cf. os artigos de Eric O. Springsted: Métaphysique de la transcendance et théorie des Metaxu chez Simone Weil, Cahiers Simone Weil, dez. 1982; e de Alain Birou, L'articulation entre le surnaturel et le social chez Simone Weil, Cabiers Simone Weil, mar. 1985 .

2 Para uma análise mais detalhada, permito-me remeter o leitor para meu artigo Relire Simone Weil, publicado em Les temps modernes, mar. 1983.

3 Esse é o titulo da obra que lhes consagra J.-L. Loubet del Bayle (ed. du Seuil, 1969).

4 Biblioteca Nacional da França, Fonds Simone Weil, Caixa IV, p. 340-343. Cito esse texto com o título de Fragment sur "L'ordre nouveau".

5 Colocado do lado da pura liberdade, do lazer.

6 Em Aristóteles, a práxis é uma atividade que não produz qualquer obra distinta do agente, uma atividade que é para si mesma o próprio fim. Seu fim é o aperfeiçoamento do próprio agente. Mesmo que se trate de atividades que produzam algo exterior a elas mesmas, seu fim é imanente. É o próprio exercício que é o fim (por exemplo, dançar ou tocar um instrumento).

7 A poiesis é uma ação que se realiza numa obra exterior ao agente. Ela tem um fim distinto de si mesma. É a atividade técnica (construir uma casa, por exemplo), atividade imperfeita, segundo Aristóteles, por correr atrás de um fim que lhe é exterior.

8 Cf. artigo de Miklos Vetö, Thèmes kantiens dans la pensée de Simone Weil, Cabiers Simone Weil, mar. 1985, p. 46.

9 Cf. P. Litthe, Action et travail chez Simone Weil, Cahiers Simone Weil, mar. 1979.

10 Quando, como é o caso para o operário moderno, a execução da tarefa é pensada pelo outro em seus mínimos detalhes e a atividade corporal fica submetida em seus mínimos gestos a uma vontade alheia, a escravização é total, pois de forma alguma pensamento e corpo encontram na matéria obstáculo, mas tão somente a cristalização da vontade de outrem. O homem já não pode ser nem mesmo um feiticeiro 
para o homem nem fazer o outro dobrar-se suplicando ou ameaçando.

11 E mais do que isso, opostas a ele.

12 Veremos mais adiante em que ponto se justifica, no espírito de Simone Weil, a analogia entre sociedade primitiva e sociedade de lazer.

13 Texto escrito talvez em 1933 - data de publicação de La révolution nécessaire de Aron \& Dandieu e no artigo de 1942 dirigido parcialmente contra Daniel Rops, que retomava as teses de L'ordre nouveau.

14 Esfera que está nas mãos da corporação, composta por aqueles que participam da produção.

15 A centralização da área da produção não-qualificada e a organização hierárquica das corporações levariam ao Estado totalitário.

16 As análises de Simone Weil (p. 145 e ss. de Réflexions...) constituem um desenvolvimento bastante sistemático das páginas dedicadas por Marx ao fetichismo no primeiro livro do Capital. Marx só analisava o caráter fetiche da mercadoria, cuja conseqüência, porém, era transformar toda a realidade social em relação entre coisas. Simone Weil retoma e prolonga a análise, enfatizando o desenvolvimento de uma realidade tornada quase totalmente autônoma com relação ao indivíduo, o que leva à subsunção real de todas as atividades individuais sob um funcionamento reificado: pensamento, trabalho, coordenação e direção no trabalho e na economia, harmonia das relações entre os homens, toda aquela atividade viva (ligada aos indivíduos e relações que entre si estabelecem) é recoberta, derrubada e substituída por mecanismos cegos os quais, diz Simone Weil, "imitam, a ponto de nos confundirem, o esforço do pensamento" (O.L., 145); e, poderíamos dizer de modo mais geral, o esforço próprio, a atividade individual. Assim, Simone Weil escreve, a respeito das máquinas automáticas, que "parecem apresentar o modelo do trabalhador inteligente, fiel, dócil e consciencioso" (ib.).

17 Cf. acima, nota 1.

18 Cf. $\mathrm{C}^{2}$, I, 64-65; e sobretudo as cartas dirigidas ao engenheiro Jacques Lafitte, publicadas em Cahiers Simone Weil, set. 1980. A obra de J. Lafitte, Réflexions sur la science des machines, foi reeditada pela editora Vrin em 1972.

19 Esta primeira parte do texto é encontrada em Robert Chenavier, in C.S. W., X-4, dez. 1987.

20 Cabiers Simone Weil, X-4, dez. 1987.

21 Particularmente em seus dois últimos livros: Adieux an prolétariat, Ed. Galilée, 1980, nova ed. na col. Points) e Les chemins du paradis (Ed. Galilée, 1983).

22 Possibilidade evocada igualmente por Hannah Arendt em Condition de l'homme moderne, p. 147 e ss.

23 Cf. Adret, Travailler deux heures par jour, Ed. du Seuil, col. Points

24 Ao oposto do trabalho produtivo, o trabalho de reprodução é aquele cujo resultado não pode ser conservado nem acumulado (limpeza, manutenção, preparação dos 
alimentos). Esses trabalhos, que devem ser executado e repetidos todos os dias, eram na Antigüidade trabalho de escravos.

25 O modelo americano e o futuro da esquerda, em Autogestions, n. 19, maio 1985, p. 12.

26 O grifo é meu, pois Simone Weil menciona sempre uma única esfera de trabalho, a do trabalho necessário.

27 Cf. o artigo de Patrice Rolland, Simone Weil et le syndicalisme révolutionnaire, Cabiers Simone Weil, dez. 1980, particularmente p. 256-262.

28 Algumas concepções, pois há outras em Marx, particularmente no fim do livro III do Capital.

29 E cada proletário em particular.

30 É interessante observar que, nos anos 60, S. Mallet (La nouvelle classe ouvrière, ed. du Seuil), R. Richta (La civilisation an Carrefour, ed. Anthropos, reedit., Seuil, col. Points) e o próprio André Gorz (Stratégie ouvrière et néo-capitalisme, ed. du Seuil) pensaram que o aperfeiçoamento das técnicas de produção e sua automatização "iriam suprimir o trabalho não-qualificado e deixariam apenas subsistir os trabalhadores técnicos em nível relativamente elevado, com visão global dos processo tecnológico-econômicos e capazes de autogerir a produção" (Gorz, Adieux au prolétariat, p. 34). Enganaram-se, como o salienta agora André Gorz.

$31 \mathrm{O}$ trabalho heterônomo é determinado em exterioridade por um sistema de relações para o qual cada um contribui, mas sem as ter querido e sem que seja possível querê-las. Essa é a esfera do trabalho socialmente necessário.

32 Uma atividade autônoma não tem outro fim senão a si mesma. É a possibilidade que tem o agente de ser ativo com relação a objetivos definidos por ele próprio e usando meios que ele pode também querer. $\mathrm{O}$ trabalho pode corresponder a tal definição, mas, em se tratando do trabalho necessário, só excepcionalmente. Uma atividade só pode ser verdadeiramente autônoma quando não for economicamente necessária.

33 Como Marx finalmente reconhece, quando escreve no livro III do Capital: "O reino da liberdade só começa no momento em que cessa o trabalho ditado pela necessidade e pelos fins exteriores". Ressalta, assim, que o reino da liberdade se situa "pela própria natureza, além da esfera da produção material propriamente dita" (Oeuvres, Bibl. de la Pléiade, 1968, t. II, p. 147).

$34 \mathrm{E}$ na qual trabalhar seria um direito e um dever.

35 O leitor interessado por esses problemas poderá consultar André Gorz, Les chemins $d u$ paradis, teses 24 e 25 .

36 Cf. A. Gorz, Allocation universelle: version de droite et version de gauche, La Revue Nouvelle, Bruxelas, abr. 1985.

37 Cf. Les chemins du paradis, p. 25 e ss.

38 Inspiro-me nesta parte na distinção entre axiologia relativa e axiologia absoluta, 
desenvolvida por André Gorz em Fondements pour une morale, ed. Galilée, 1977, p. 499 e ss.

39 Com a única diferença que, no trabalho, o homem está submetido às necessidades da natureza exterior e não às das próprias faculdades lógicas.

40 Cf. E.L., 16-17; C. II, 153-154; C.S., 38.

41 "O único termo capaz de exprimir adequadamente a intuição fundamental (de Simone Weil): a da vocação auto-aniquiladora dos seres humanos" (Miklos Vetö, La métaphysique religieuse de Simone Weil, ed. Vrin, 1971, p. 19).

42 Desvencilhado dessa necessidade, o trabalho passaria a ser - seja forçado (por razões de manutenção de uma estrutura hierarquizada de determinada forma), seja pura atividade educativa - aprendizagem da necessidade (agora, no sentido que lhe dá Simone Weil). Mas, o que é próprio da aprendizagem é ela se encerrar ao atingir o objetivo. Obrigar o homem a trabalhar além - ou independentemente - do exigido pela reprodução da vida significaria sujeitá-lo eternamente a uma função sem necessidade vital, cuja finalidade seria erguer obstáculos que fornecessem a oportunidade de vencer a si mesmo.

\section{Bibliografia}

Segue a lista das obras de Simone Weil citadas no texto com as suas respectivas abreviações:

O.L. - Oppression et liberté. Paris, Gallimard, 1995.

E.L. - Écrits de Londres et dernières lettres. Paris, Gallimard, 1957.

E. - L'Enracimement. Paris, Gallimard, 1962.

C.O. - La condition ouvriére. Paris, Gallimard, 1964.

E.H.P. - Écrits historiques et politique. Paris, Gallimard, 1960.

S. - Sur la science. Paris, Gallimard, 1966.

C., I. - Cahiers. Paris, Plon; v. I, 1951.

C $^{2}$., I. - Cahiers. $2^{\text {a }}$ ed., v. I, Paris, Plon, 1979.

C.S. - La Connaissance surnaturelle. Paris, Gallimard, 1950.

Robert Chenavier é presidente da Association pour l'étude de la pensée de Simome Weil, sediada em Paris.

Palestra feita pelo autor em 6 de dezembro de 1986, à rua Monticelli. Reproduzida em Cabiers Simone Weil, X-3, set. 1987.

Tradução de Jean Briant. O original em francês - Civilisation du travail ou civilisation du temps libre? (Actualité de la pensée de Simone Weil) - encontra-se à disposição do leitor no IEA-USP para eventual consulta. 